\title{
Mineral chemistry of Pangidi basalt flows from Andhra Pradesh
}

\author{
P V Nageswara RaO ${ }^{1, *}$, P C Swaroop ${ }^{2}$ and Syed Karimulla ${ }^{1}$ \\ ${ }^{1}$ Department of Geology, Acharya Nagarjuna University, Nagarjunanagar 522 510, Andhra Pradesh, India. \\ ${ }^{2}$ Department of Geology, C.R. Reddy College, Eluru 534 003, Andhra Pradesh, India. \\ ${ }^{*}$ Corresponding author.e-mail: pusapati_vnr@yahoomail.com
}

This paper elucidates the compositional studies on clinopyroxene, plagioclase, titaniferous magnetite and ilmenite of basalts of Pangidi area to understand the geothermometry and oxybarometry conditions. Petrographic evidence and anorthite content (up to 85\%) of plagioclase and temperature estimates of clinopyroxene indicate that the clinopyroxene is crystallized later than or together with plagioclase. The higher An content indicates that the parent magma is tholeiitic composition. The equilibration temperatures of clinopyroxene $\left(1110-1190^{\circ} \mathrm{C}\right)$ and titaniferous magnetite and ilmenite coexisting mineral phases $\left(1063-1103^{\circ} \mathrm{C}\right)$ are almost similar in lower basalt flow and it is higher for clinopyroxene $\left(900-1110^{\circ} \mathrm{C}\right)$ when compared to titaniferous magnetite and ilmenite coexisting mineral phases $\left(748-898^{\circ} \mathrm{C}\right)$ in middle and upper basalt flows. From this it can be inferred that the clinopyroxene is crystallized earlier than $\mathrm{Fe}-\mathrm{Ti}$ oxide phases reequilibration, which indicates that the clinopyroxene temperature is the approximate eruption temperature of the present lava flows. The wide range of temperatures $\left(900-1190^{\circ} \mathrm{C}\right)$ attained by clinopyroxene may point out that the equilibration of clinopyroxene crystals initiated from depth till closer to the surface before the melt erupted. Pangidi basalts follow the QFM buffer curve which indicates the more evolved tholeiitic composition. This suggests the parent tholeiitic magma suffered limited fractionation at high temperature under increasing oxygen fugacity in lower basalt flow and more fractionation at medium to lower temperatures under decreasing oxygen fugacity conditions during cooling of middle and upper basalt flows. The variation of oxygen fugacity indicates the oxidizing conditions for lower basalt flow (9.48-10.3) and extremely reducing conditions for middle (12.1-15.5) and upper basalt (12.4-15.54) flows prevailed at the time of cooling. Temperature vs. $\left(\mathrm{FeO}+\mathrm{Fe}_{2} \mathrm{O}_{3}\right) /\left(\mathrm{FeO}+\mathrm{Fe}_{2} \mathrm{O}_{3}+\mathrm{MgO}\right)$ data plots for present basalts suggested the lower basaltic flow is formed at higher temperatures while the middle and upper basalt flows at medium to lower temperatures. The lower basalt flow is represented by higher temperatures which shows high modal values of opaques and glass whereas the medium to lower temperatures of middle and upper flow are caused by vesicular nature which contain larger content of gases and humid to semi-arid conditions during cooling.

\section{Introduction}

Rajahmundry Trap flows of eastern peninsular India occupy $\sim 100 \mathrm{~km}^{2}$ centered on the Krishna-
Godavari basin, extend $\sim 70 \mathrm{~km}$ offshore in the subsurface. Striking NE-WSW, these lava flows dip $\sim 5^{\circ}$ to the SE towards Bay of Bengal. However, a subsurface extent of $7500-10,000 \mathrm{~km}^{2}$, with

Keywords. Mineral chemistry; geothermometry; oxygen fugacities; basalt flows; Andhra Pradesh. 


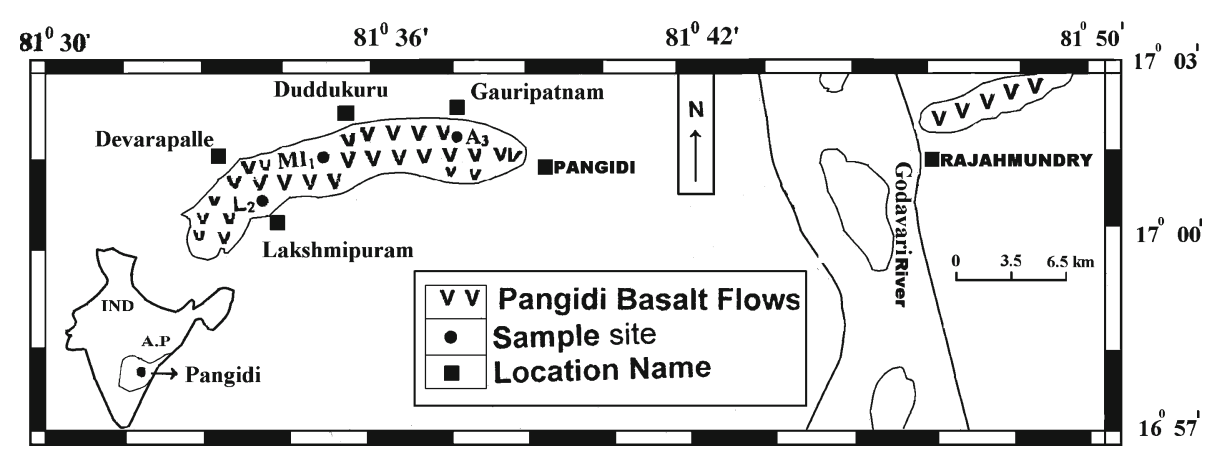

Figure 1. The location map of Pangidi area of Andhra Pradesh.

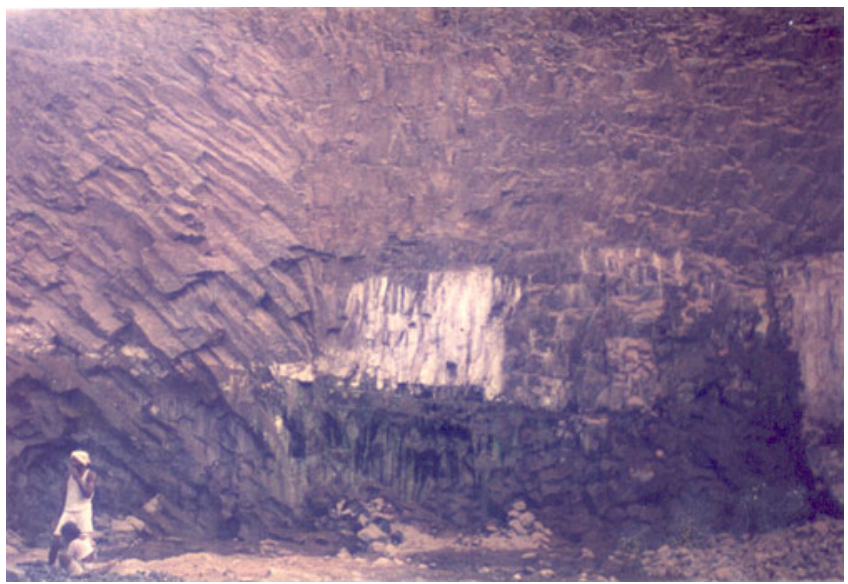

Figure 2. Field photograph of columnar jointing observed in the lower basalt flow from Arlametta quarry near Duddukuru.

a thickness ranging up to $150 \mathrm{~m}$ have been deduced from the data of local groundwater and oil wells of ONGC (Raju et al 1965; Lakshminarayana et al 2010). These lava flows, relatively small outcrops, occur on the west and east banks of Godavari river around Pangidi and Rajahmundry towns, respectively (figure 1). Despite lying $\sim 400 \mathrm{~km}$ east of the nearest outcrop of Deccan Trap Basalt, the Rajahmundry Traps have long been considered the eastward extension of Deccan Traps, the bulk of which were erupted near the Cretaceous-Tertiary (K-T) boundary (65.6 Ma; Baksi 2001; Rao et al 2002; Knight et al 2003). On the basis of their similarities with other Continental Flood Basalt (CFB) provinces of the world, these traps have been interpreted that they were transported along a Krishna-Godavari paleovalley travelling over a distance of $\sim 1000 \mathrm{~km}$ from west to east coast of India (Baksi et al 1994; Knight et al 2003; Self et al 2008; Anne and Widdowson 2008).

The present area of investigation is confined to the lava flows from the west bank of Godavari

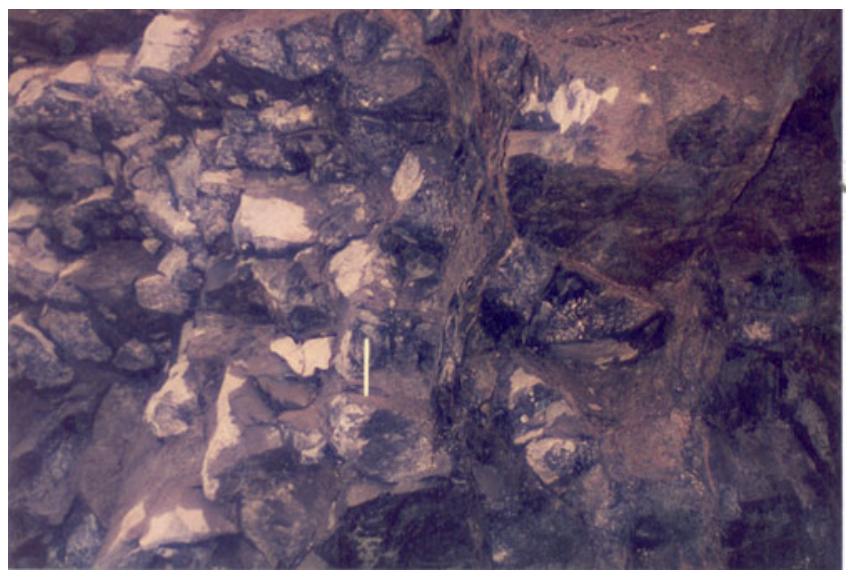

Figure 3. Field photograph of spheroidal weathering shown by upper basalt flow from Lakshmipuram.

river which occurs around Pangidi town, and covers an area of $40 \mathrm{~km}^{2}$ (figure 1). Pangidi Traps consist of three distinct basalt flows (lower, middle and upper) interbedded with two intertrappean layers I and II (Lakshminarayana et al 2010). The upper basaltic flow (UBF) is overlain by Eocene Rajahmundry sandstone formation while the lower basaltic flow (LBF) is underlain by series of late Cretaceous limestones. The LBF is well exposed in the areas of Gauripatnam, Devarapalle and Pangidi, characterized by fine grained, massive, thick $(\sim 20-30 \mathrm{~m})$, greenish and black in colour basalt, which are brecciated and show radial and columnar jointing (figure 2). The middle flow (MBF) is fine grained basalt, thin $(\sim 6-11 \mathrm{~m})$, greenish in colour, and vesicular ( $\mathrm{mm}$ size) nature observed at the western part of Duddukuru. The UBF is best exposed at Duddukuru and Lakshmipuram locations, characterized by massive, light colour, glassy, thin $(\sim 5-17 \mathrm{~m})$, fine grained basalt which on weathering gave rise to spheroidal boulders of various sizes (figure 3). A variety of volcanological features such as rootless 
cones, tumuli and dyke-like forms are recorded in the LBF (Lakshminarayana et al 2010).

Detailed studies regarding the mineral chemistry, whole rock geochemistry and geothermometry of CFB from DVP (Deccan Volcanic Province) have been attempted to understand the petrogenesis from Jawhar and Igatpuri formations (Sethna and Sethna 1988; Subba Rao et al 1988), Mahabaleswar formation (Najafi et al 1981; Mahoney et al 1982; Sen 1986; Sethna and Sethna 1988), and Sagar and Nagpur areas (Sethna et al 1987; Sethna and Sethna 1988). Ahmad and Shrivastava (2004) have discussed about compositional variations of coexisting ilmenite-magnetite mineral phases, geothermometry and petrogenesis of Mandla lava flows from eastern DVP of India.

This paper is aimed at understanding the mineral chemistry of clinopyroxene, plagioclase and coexisting phases of titaniferous magnetite and ilmenite. The geothermometry and oxybarometry implications of Pangidi basalt flows of Andhra Pradesh are also discussed in this paper.

\section{Petrography}

The LBF commonly shows subophitic to ophitic textures and occasionally exhibit porphyritic texture with a hyaloophitic textured groundmass (figure 4). The principal constituents in LBF are plagioclase and brownish non-pleochroic augite. Magnetite, ilmenite, pigeonite and glass are the accessory constituents. The MBF and UBF show

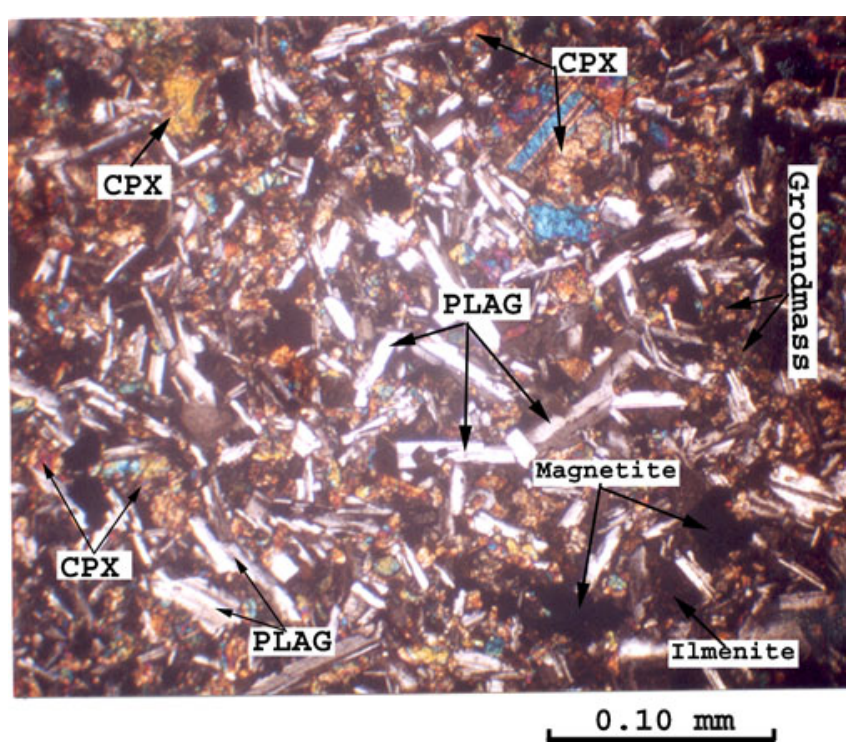

Figure 4. Photomicrograph showing fresh plagioclase laths, clinopyroxene, Ti-magnetite with subophtic texture in lower basalt flow $(\times 10)$ cross-polarized light. hemicrystalline and porphyritic, with hyaloophitic textured groundmass. Plagioclase phenocryst occurs as thin, elongated or tabular laths, varying in length from 0.1 to $0.8 \mathrm{~mm}$ and it rarely exceeds $1 \mathrm{~cm}$. Microphenocryst of augite also occurs in aggregate (figure 5). The average size of augite is about $0.25 \mathrm{~mm}$. Pigeonite is rare in association with augite. Olivine is not found in all the samples of three basalt flows. Clinopyroxene occurs mainly as granules in the intergranular spaces of plagioclase crystals. Magnetite is present as microphenocrysts. Haematite and ilmenite occur as platelets in mesostasis. Fe-Ti oxides occur in sizes from 0.05 to $0.1 \mathrm{~mm}$. Mesostasis consists of devitrified glass containing plagioclase laths, pyroxene granules and platelets of haematite and ilmenite. The groundmass is generally fine grained with the average grain size of $<0.15 \mathrm{~mm}$. Feldspar, pyroxene and iron ores are invariably present, together with glass. There is a subtle variation in the mineralogical composition among the LBF, MBF and UBF. The modal compositions (vol. $\%$ ) of plagioclase, pyroxene, $\mathrm{Fe}-\mathrm{Ti}$ oxides and glass present in $\mathrm{LBF}, \mathrm{MBF}$ and $\mathrm{UBF}$ are given in table 1.

\section{Mineral chemistry}

Three basalt samples $\mathrm{A}_{3}, \mathrm{MI}_{1}$ and $\mathrm{L}_{2}$ representing $\mathrm{LBF}, \mathrm{MBF}$ and $\mathrm{UBF}$ respectively, were selected for the chemical analyses. The analyses of plagioclase (PLAG), clinopyroxene (CPX), titaniferous magnetite and ilmenite (Fe-Ti oxides) are carried out at Geochemistry Division, National

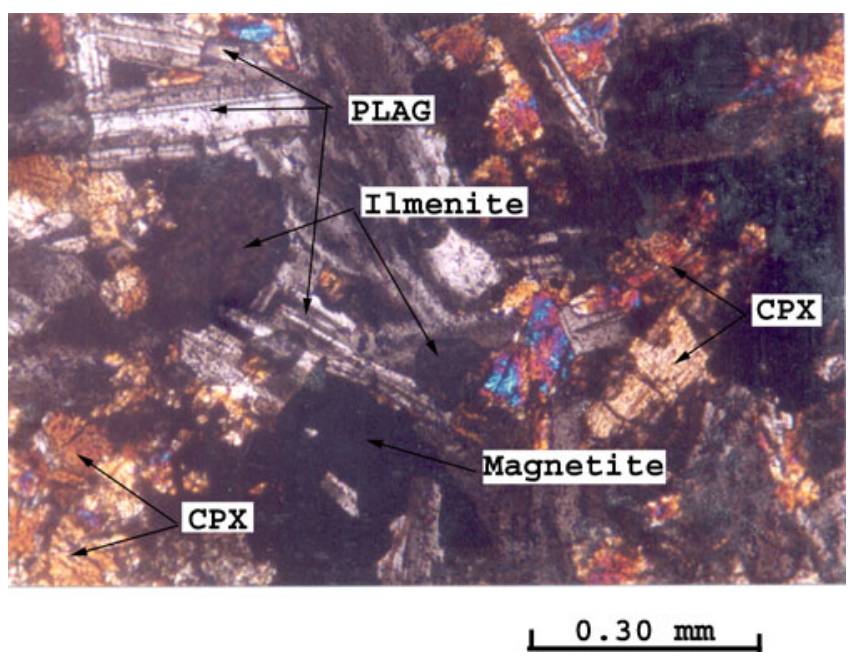

Figure 5. Photomicrograph showing the phenocrysts and microphenocrysts of plagioclase laths, clinopyroxene and $\mathrm{Fe}-\mathrm{Ti}$ oxide minerals $(\times 10)$ cross-polarized light. 
Table 1. Modal composition (vol.\%) of basalt flows of Pangidi area, Andhra Pradesh.

\begin{tabular}{|c|c|c|c|c|c|c|}
\hline \multirow{2}{*}{$\begin{array}{l}\text { Flow type/ } \\
\text { sample no. }\end{array}$} & \multicolumn{2}{|c|}{ Phenocryst } & \multicolumn{4}{|c|}{ Groundmass } \\
\hline & Plagioclase & Clinopyroxene & Plagioclase & Clinopyroxene & Fe-Ti oxides & Glass \\
\hline $\operatorname{LBF}\left(\mathrm{A}_{3}\right)$ & 10.2 & 12.3 & 31.6 & 28.4 & 10.7 & 6.8 \\
\hline $\operatorname{MBF}\left(\mathrm{MI}_{1}\right)$ & 23.1 & 24.3 & 16.4 & 15.8 & 6.0 & 10.1 \\
\hline $\mathrm{UBF}\left(\mathrm{L}_{2}\right)$ & 22.0 & 24.1 & 19.3 & 17.2 & 5.2 & 12.2 \\
\hline
\end{tabular}

Geophysical Research Institute, Hyderabad using Cameca Camebax Electron Microprobe (EPMA). The accelerating voltage used was $15 \mathrm{kV}$ and sample current measured on a brass was $5 \mathrm{nA}$. Data acquisition and data reduction were done by an online PDP11/03 computer, using the rigorous ZAF correlation programme after Hennoc and Maurice (1978). Both synthetic and homogenous standards were used. A total of 51 grains from the three basaltic samples, including the phenocryst and groundmass, were probed from the core to rim for PLAG and CPX and single points at core for Fe-Ti oxides.

\section{Results and discussion}

The chemical analyses obtained for clinopyroxene, plagioclase and $\mathrm{Fe}-\mathrm{Ti}$ oxides are presented in tables 2, 3 and 4 and also discussed below.

\subsection{Plagioclase}

Plagioclase (PLAG) phenocrysts are abundant and occur as euhedral to subhedral crystals. Sometimes PLAG crystals form interlocking groups with individual phenocrysts of varying sizes (figures 4 and 5). PLAG phenocrysts rarely contain inclusions of apatite. The overall An range is $85.3-51.5 \%$, with the plots mostly in labrodorite and one each in the bytowinite and anorthite fields. Probing the sample no. $\mathrm{MI}_{1}$, yielded a maximum An content of $85.3 \%$ and minimum of $51.5 \%$. The An of phenocrysts varies from 61.6 to $72.4 \%$ in core and 63.2 to $85.3 \%$ in rim, while it is in groundmass, varying from 51.5 to $57.8 \%$ in core and 59.6 to $68.7 \%$ in rim. The overall composition of An content suggests that the PLAG mostly belongs to labrodorite variety (table 2). The Or is in low content $(<2 \%)$. PLAG plotting in the ternary classification diagram $\mathrm{Ab}-\mathrm{An}$-Or (figure 6) shows that there may be some overlap between groundmass and phenocryst compositions, which indicate the simultaneous crystallization of both phenocryst and groundmass. The lack of coexisted alkali feldspar with PLAG in the present area (figure 2 and 3), precludes the possibility of estimation of the liquidus temperature of parental magma.

The petrographic evidence that the PLAG was the liquidus phase is confirmed by the occurrence of individuals relatively rich in anorthite component (up to 85\%). The overall measured range of PLAG composition plots very close to the An-Ab join (figure 6) due to low amounts of orthoclase component. It is evident from figure 7 that $\mathrm{SiO}_{2}$ shows weak negative correlation with $\mathrm{CaO}$ and $\mathrm{Al}_{2} \mathrm{O}_{3}$ and positive correlation with $\mathrm{Na}_{2} \mathrm{O}$. However, the LBF and UBF show similarity in $\mathrm{CaO}$, $\mathrm{Al}_{2} \mathrm{O}_{3}$ and $\mathrm{Na}_{2} \mathrm{O}$ contents while the MBF have almost similar $\mathrm{Na}_{2} \mathrm{O}$, but higher contents of $\mathrm{CaO}$ and $\mathrm{Al}_{2} \mathrm{O}_{3}$ compared to $\mathrm{LBF}$ and UBF (table 2). The slight increase in the amounts of $\mathrm{Al}_{2} \mathrm{O}_{3}$, $\mathrm{CaO}$ in $\mathrm{MBF}$ is expected due to significant contamination that arises from thick intertrappean bed-I, which is composed of limestone and clay (Lakshminarayana et al 2010). Transect across the phenocryst grains of LBF and UBF indicate normal chemical zoning because they have narrow difference in An content between the core (high) and rim (low). MBF phenocryst yields very long transect displaying the variable zoning because of much difference in An content between core and rim (figure 8). The transect across the groundmass shows no difference between core and rim An contents of LBF and UBF because of rapid cooling after eruption and more difference in between core and rim of MBF due to slow cooling after eruption. The overall An content (57.5-85.3\%) suggests that the Pangidi basalts are derived from parent magma is of tholeiitic composition. The difference in phenocryst volume proportions of three flows (table 1) inferred that the PLAG involvement in fractionation process is less in the LBF and it is significant in the $\mathrm{MBF}$ and $\mathrm{UBF}$ during differentiation.

\subsection{Clinopyroxene}

Clinopyroxene (CPX) occurs as microphenocrysts and granules in the intergranular spaces of PLAG crystals (figures 2 and 3 ). The variation diagram of $\mathrm{SiO}_{2}$ vs. $\mathrm{MgO}, \mathrm{FeO}(t)$ and $\mathrm{CaO}$ (figure 9) shows that the percentages of the above plotted oxides are 


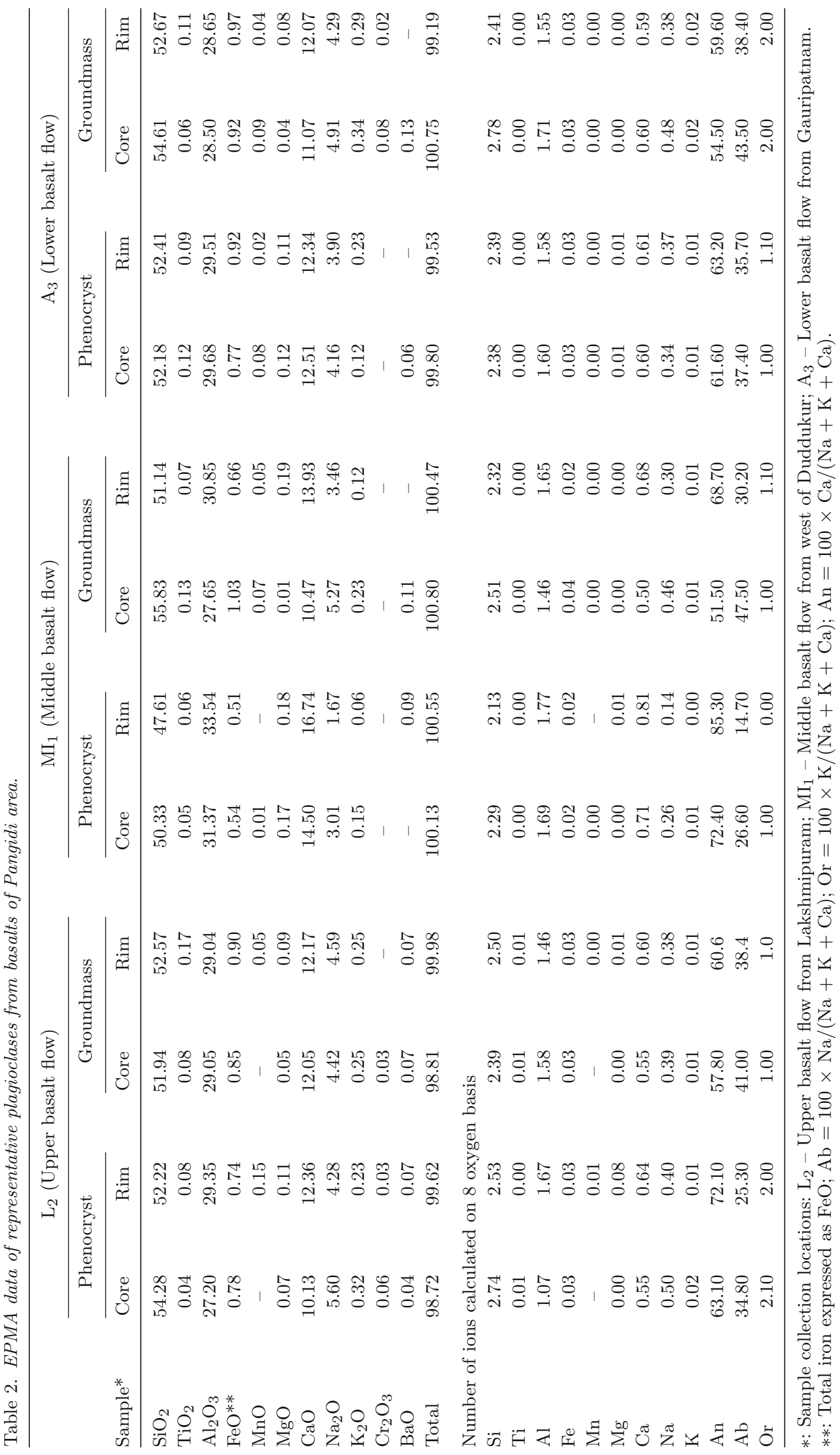




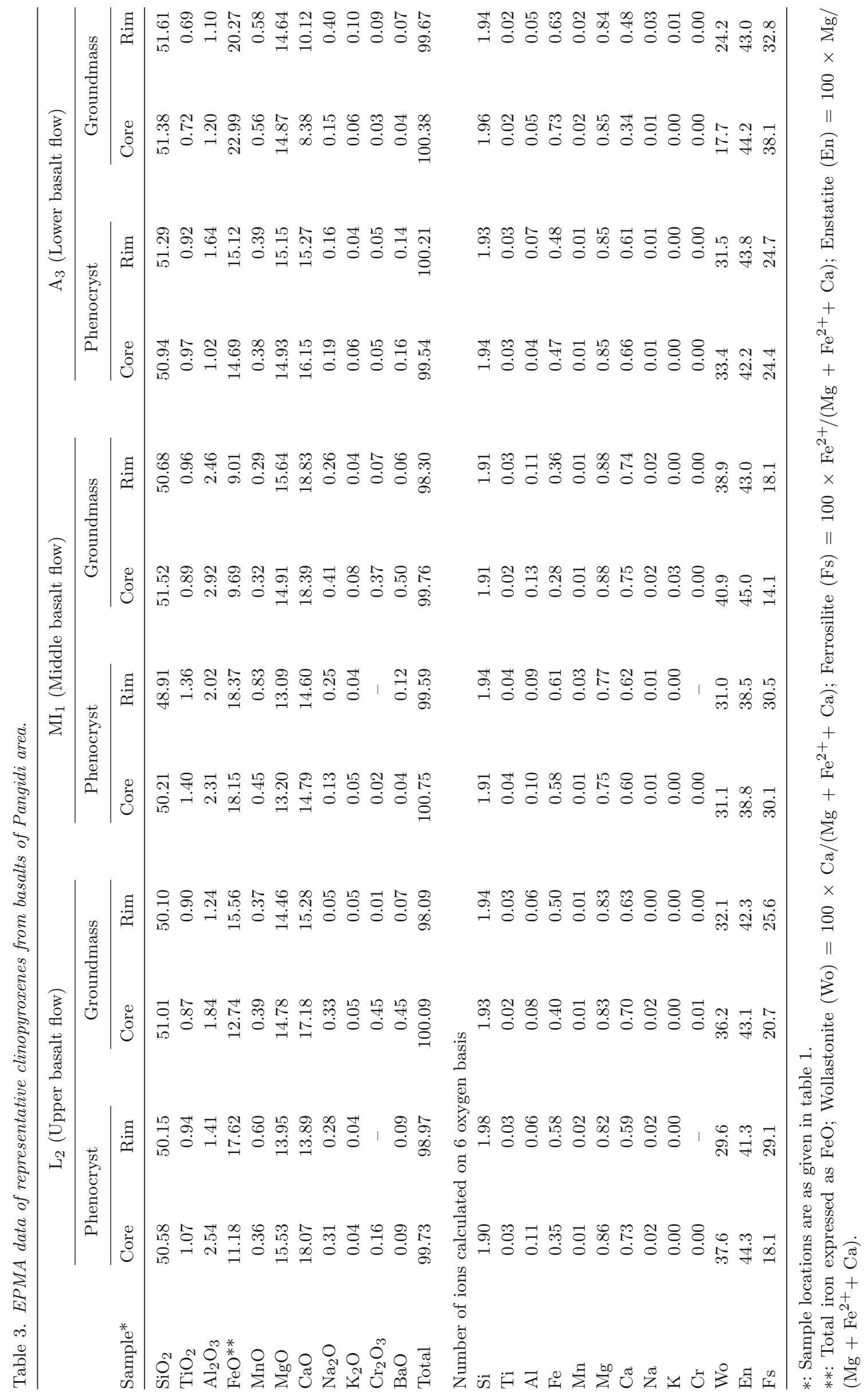


Table 4. EPMA data (core) of representative Ti-magnetite and ilmenites from basalts of Pangidi area.

\begin{tabular}{|c|c|c|c|c|c|c|}
\hline \multirow{2}{*}{$\frac{\text { Sample }}{\text { Oxides }}$} & \multicolumn{2}{|c|}{$\mathrm{L}_{2}$ (Upper basalt flow) } & \multicolumn{2}{|c|}{$\mathrm{MI}_{1}$ (Middle basalt flow) } & \multicolumn{2}{|c|}{$\mathrm{A}_{3}$ (Lower basalt flow) } \\
\hline & Ti-magnetite & Ilmenite & Ti-magnetite & Ilmenite & Ti-magnetite & Ilmenite \\
\hline $\mathrm{SiO}_{2}$ & 0.98 & 0.06 & 0.68 & 0.08 & 0.65 & 0.05 \\
\hline $\mathrm{TiO}_{2}$ & 30.26 & 50.62 & 25.10 & 52.01 & 27.31 & 51.95 \\
\hline $\mathrm{Al}_{2} \mathrm{O}_{3}$ & 2.48 & 0.01 & 2.18 & 0.02 & 1.31 & 0.01 \\
\hline $\mathrm{FeO}^{*}$ & 59.32 & 48.43 & 66.66 & 48.20 & 62.43 & 49.38 \\
\hline $\mathrm{MnO}$ & 0.51 & 0.47 & 0.81 & 0.51 & 0.46 & 0.58 \\
\hline $\mathrm{MgO}$ & 1.02 & 0.70 & 0.82 & 0.55 & 1.29 & 0.59 \\
\hline $\mathrm{CaO}$ & 0.35 & 0.08 & 0.13 & 0.03 & 0.27 & 0.05 \\
\hline $\mathrm{Na}_{2} \mathrm{O}$ & 0.02 & 0.05 & 0.02 & 0.01 & 0.04 & 0.03 \\
\hline $\mathrm{K}_{2} \mathrm{O}$ & 0.04 & 0.04 & 0.05 & 0.05 & 0.07 & 0.05 \\
\hline $\mathrm{Cr}_{2} \mathrm{O}_{3}$ & 0.10 & 0.01 & - & - & 0.17 & 0.01 \\
\hline $\mathrm{BaO}$ & 0.47 & 1.00 & 0.41 & 1.10 & 0.52 & 1.08 \\
\hline Total & 95.55 & 101.47 & 98.84 & 102.56 & 94.51 & 103.78 \\
\hline \multicolumn{7}{|c|}{ Number of ions calculated on 32 and 6 oxygen basis of Ti-magnetite and ilmenite respectively } \\
\hline $\mathrm{Si}$ & 0.30 & 0.00 & 0.21 & 0.00 & 0.21 & 0.00 \\
\hline $\mathrm{Ti}$ & 7.01 & 1.93 & 5.99 & 1.97 & 6.60 & 1.94 \\
\hline $\mathrm{Al}$ & 0.90 & 0.00 & 0.81 & 0.00 & 0.49 & 0.00 \\
\hline $\mathrm{Fe}$ & 15.29 & 2.05 & 17.69 & 2.01 & 16.77 & 2.05 \\
\hline $\mathrm{Mn}$ & 0.13 & 0.02 & 0.22 & 0.02 & 0.12 & 0.02 \\
\hline $\mathrm{Mg}$ & 0.47 & 0.05 & 0.39 & 0.04 & 0.62 & 0.04 \\
\hline $\mathrm{Ca}$ & 0.11 & 0.00 & 0.04 & 0.00 & 0.09 & 0.00 \\
\hline $\mathrm{Na}$ & 0.01 & 0.00 & 0.01 & 0.00 & 0.02 & 0.00 \\
\hline K & 0.01 & 0.00 & 0.02 & 0.00 & 0.03 & 0.00 \\
\hline \multicolumn{7}{|c|}{ Recalculated analysis of ulvospinel and ilmenite basis respectively** } \\
\hline $\mathrm{FeO}$ & 5.64 & 9.91 & 17.45 & 6.46 & 6.14 & 13.14 \\
\hline $\mathrm{Fe}_{2} \mathrm{O}_{3}$ & 55.92 & 38.82 & 50.62 & 42.21 & 56.76 & 37.53 \\
\hline
\end{tabular}

*: Sample locations are as given in table 1.

**: The calculation of molecular percentages of ulvospinel and ilmenite were done by ITHERM program developed by Rameshwara Rao et al (1991).

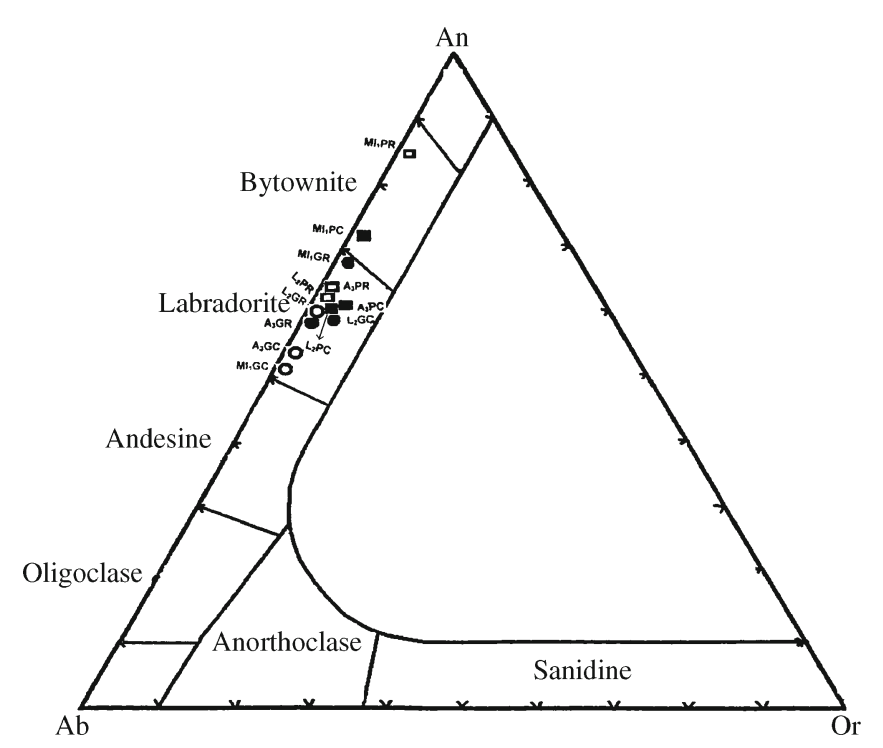

Figure 6. Ternary classification diagram of $\mathrm{Ab}-\mathrm{An}-\mathrm{Or}$ for feldspars. $\mathrm{A}_{3}, \mathrm{MI}_{1}$ and $\mathrm{L}_{2}$ denote samples; PC, PR, GC and GR denote phenocryst core, phenocryst rim, groundmass core and groundmass rim. in similar range for $\mathrm{LBF}, \mathrm{UBF}$ and $\mathrm{MBF}$ (except phenocryst core). There is a slight decrease of $\mathrm{MgO}$ and $\mathrm{CaO}$ contents at the rim relative to the core, and slight increase of $\mathrm{FeO}$ at core relative to the rim is observed for both the phenocryst (except MBF) and groundmass (except LBF) (table 3). Based on the above oxide distribution between core and rim there is no distinct compositional zoning noticed in CPX grains. It suggests that the crystallization movement in phenocryst and groundmass proceeds to lower pressures in the melt.

The observed composition of phenocryst core is $\mathrm{En}_{38-44} \mathrm{Wo}_{31-37} \mathrm{Fs}_{18-30}$ and in rim is $\mathrm{En}_{38-43}$ $\mathrm{Wo}_{29-31} \mathrm{Fs}_{24-30}$, while it is for groundmass core is $\mathrm{En}_{43-45} \mathrm{Wo}_{17-40} \mathrm{Fs}_{20-38}$ and in rim is $\mathrm{En}_{42-44}$ $\mathrm{Wo}_{24-38} \mathrm{Fs}_{18-32}$ (table 3 ). The plotting of phenocryst and groundmass data in the quadrilateral classification diagram Di-Hd-En-Fs shows that the augite is predominant pyroxene with minor subcalcic augite (figure 10). The chemical trend of increasing Fs content at decreasing Wo components and low $\mathrm{Ti}(<0.04$ a.p.f.u), are typical of 


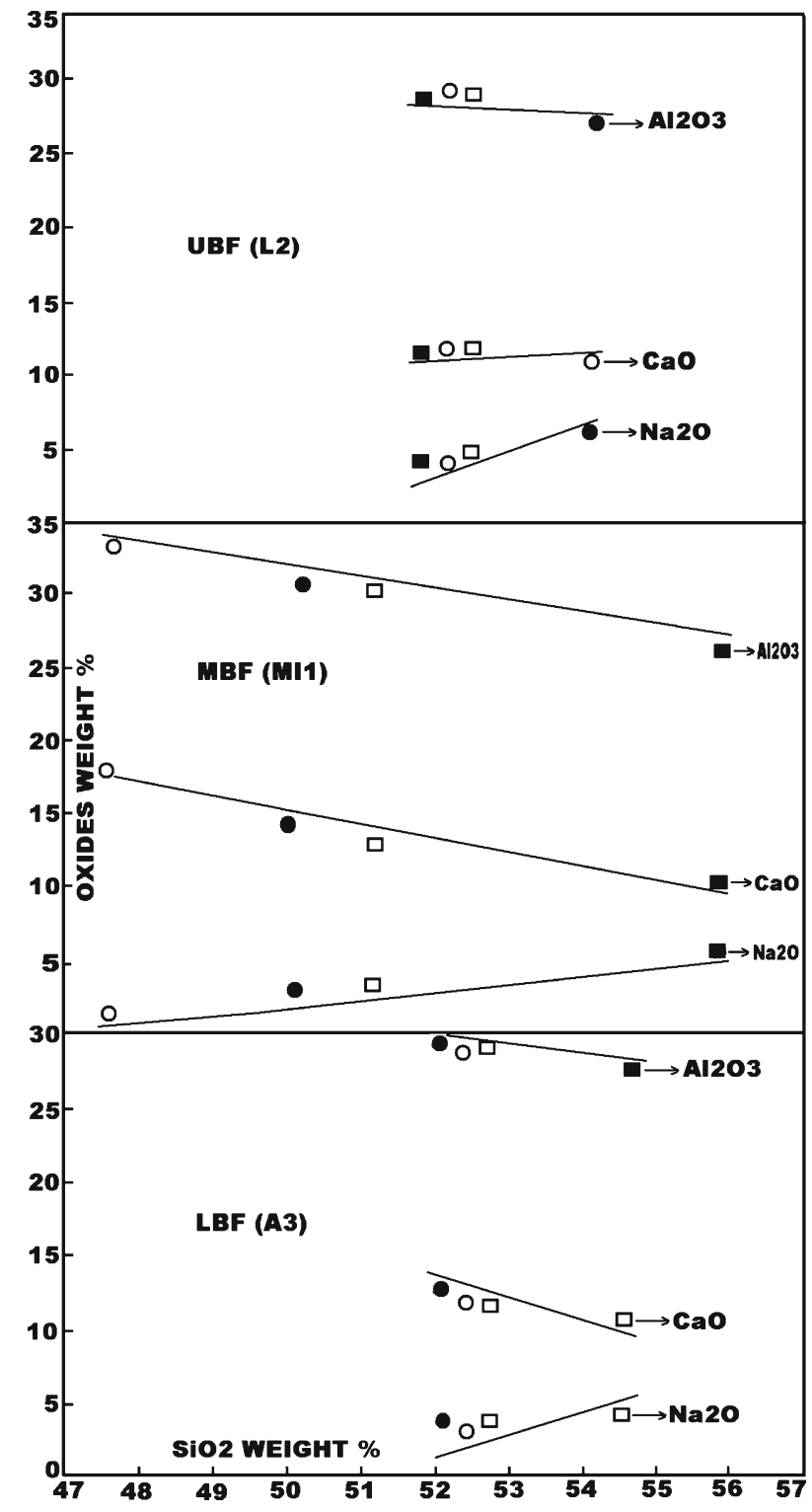

Figure 7. Variation diagram of $\mathrm{SiO}_{2}$ vs. $\mathrm{Na}_{2} \mathrm{O}, \mathrm{CaO}$ and $\mathrm{Al}_{2} \mathrm{O}_{3}$ for plagioclase feldspar. The enrichment of $\mathrm{Na}_{2} \mathrm{O}$ in cores and $\mathrm{CaO}$ and $\mathrm{Al}_{2} \mathrm{O}_{3}$ in rims is observed.

CPX from mafic tholeiitic magma. The observation of more data of phenocryst and groundmass, which is almost parallel to the solidus trend for augite composition of Skaergaard tholeiite (Brown and Vincent 1963), indicates crystal fractionation process involved during cooling as reported by Carmichael (1967b). Further, the formation of subcalcic augite in LBF is caused by sudden change in the cooling as suggested by Brown (1967).

Lindsley's (1983) graphical thermometer is used to deduce the equilibration temperatures of CPX of present study area. The flowwise temperature estimates for $\mathrm{LBF}, \mathrm{MBF}$ and $\mathrm{UBF}$ are presented in table 5. Figure 11 shows that the majority of the CPX data fall in between 1200 and $1000^{\circ} \mathrm{C}$

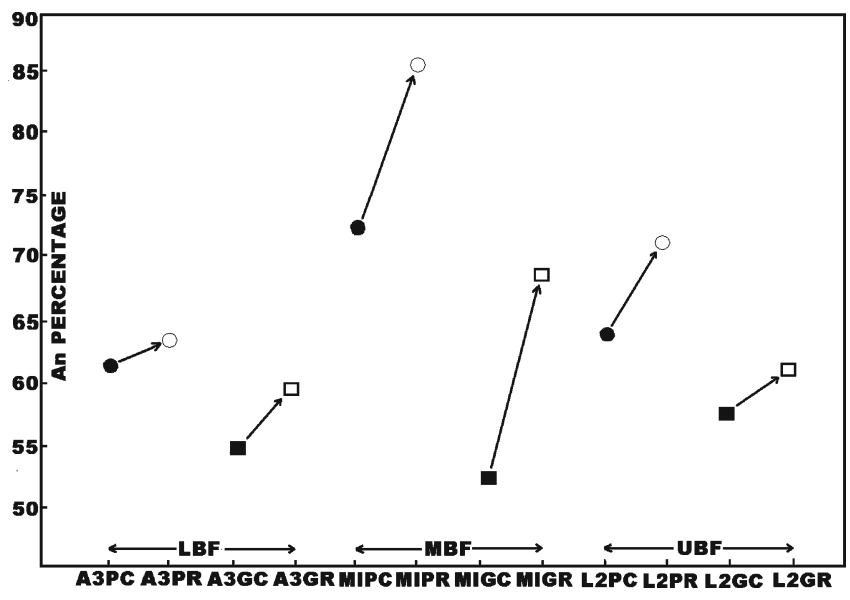

Figure 8. A plot of anorthite percentage across a core to rim transect in a representative phenocryst and groundmass demonstrates that plagioclase crystals show chemical zoning resulting in anorthite enriched rims. Arrow head indicates enrichment trend of An from core to rim.

isotherms. Only two data plots fall in around $900^{\circ} \mathrm{C}$, because of anomalous in $\mathrm{Na}_{2} \mathrm{O}$ and $\mathrm{TiO}_{2}$ contents. The temperature estimates of CPX liquidus $\left(\sim 1000-1190^{\circ} \mathrm{C}\right)$ depict that the CPX is crystallized later than or together with PLAG. It is also inferred that the equilibration of CPX crystals initiated from depth till closer to the surface before the melt erupted.

\subsection{Titaniferous magnetite}

Titaniferous magnetite occurs rarely as microphenocrysts or groundmass. The sample had normalized weight percentages for $\mathrm{FeO}$ (total) and $\mathrm{TiO}_{2}$ each around 65 and $35 \%$ (table 4). The data of magnetite-ulvospinel solid solution are presented in table 4 . They have been calculated to give $\mathrm{Fe}_{2} \mathrm{O}_{3}$ per cent and ulvospinel molecules. It may be seen that very small amounts of $\mathrm{SiO}_{2}$, $\mathrm{Al}_{2} \mathrm{O}_{3}, \mathrm{MnO}, \mathrm{MgO}$ and $\mathrm{CaO}$ are present along with the major element. Little concentration of $\mathrm{Cr}_{2} \mathrm{O}_{3}(0.10-0.17 \%)$ and $\mathrm{BaO}(0.42-0.52 \%)$ are also present in the analysed samples.

\subsection{Ilmenite}

In comparison, the ilmenite-hematite solid solution contains much less $\mathrm{SiO}_{2}, \mathrm{Al}_{2} \mathrm{O}_{3}, \mathrm{MgO}$, and $\mathrm{CaO}$ though $\mathrm{Na}_{2} \mathrm{O}, \mathrm{K}_{2} \mathrm{O}$, and $\mathrm{Cr}_{2} \mathrm{O}_{3}$ are present in almost similar amounts, but $\mathrm{BaO}$ content shows high concentration. These crystals did not visually show zoning and had distinct grain boundaries that displayed no apparent chemical alteration. The compositions of the grains were 


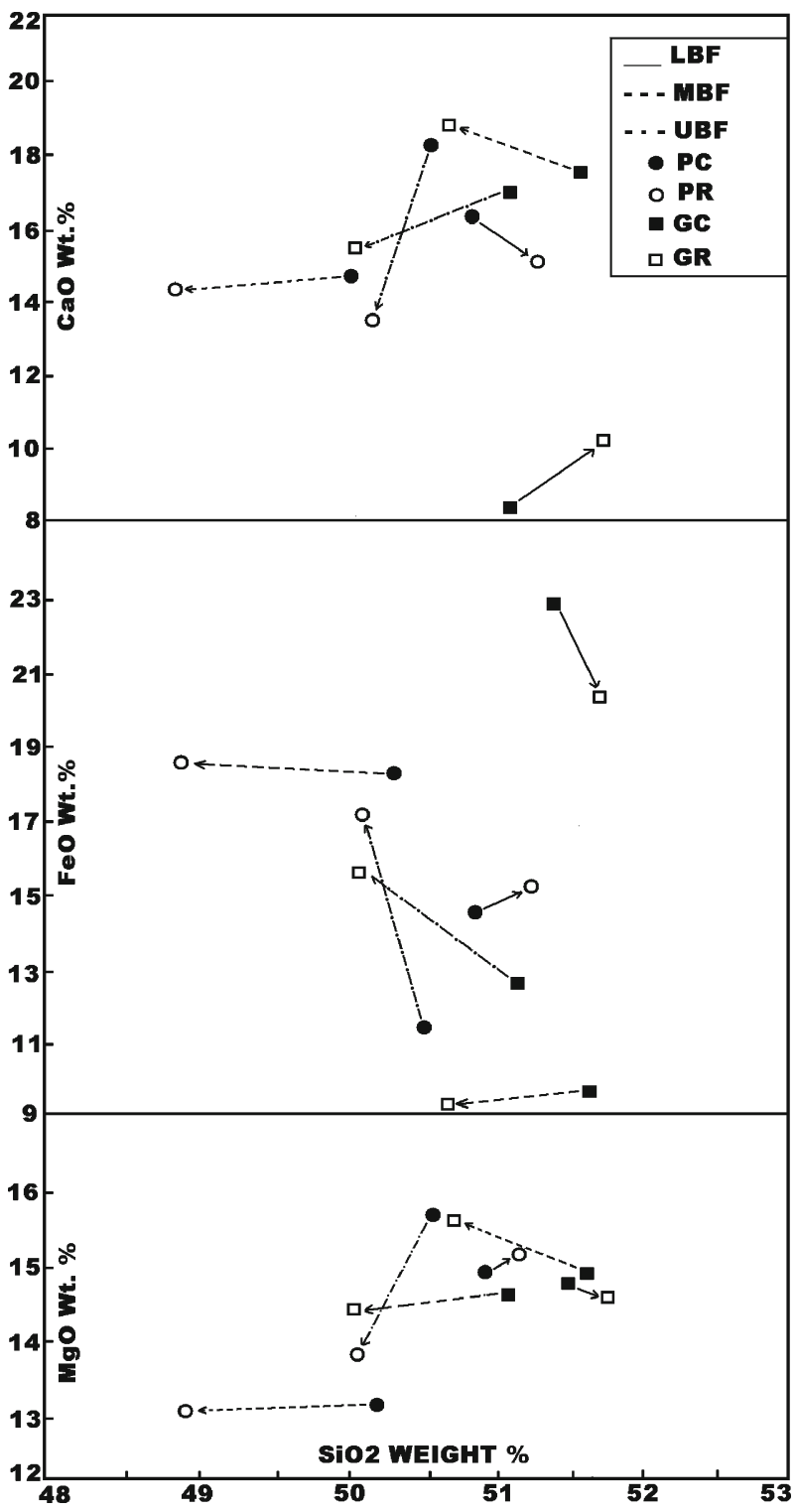

Figure 9. Harker variation diagram of $\mathrm{SiO}_{2}$ vs. $\mathrm{MgO}, \mathrm{FeO}(t)$ and $\mathrm{CaO}$ for pyroxene phenocryst and groundmass. PC, PR, GC and GR denote the phenocryst core, phenocryst rim, groundmass core and groundmass rim. Arrow head indicates the enrichment/depletion of oxide content from core to rim. fairly consistent in three samples regardless of grain size (table 4). These samples had normalized weight percentage values of $\mathrm{FeO}$ (total) and $\mathrm{TiO}_{2}$ each around $50 \%$.

The present study adopted the recalculation schemes of Carmichael (1967a) and Lindsley and Spencer (1982) to obtain the ulvospinel and ilmenite molecule percentages and Powell and Powell (1977) and Lindsley and Spencer (1982) thermometers for estimation of equilibration temperatures. The oxygen fugacity $\left(-\log \mathrm{fO}_{2}\right)$ values are derived by using the mathematical solution (Spencer and Lindsley 1981).

The equilibration temperatures of $\mathrm{Fe}-\mathrm{Ti}$ oxides are between 1076 and $894^{\circ} \mathrm{C}$, as per the thermometer of Powell and Powell (1977), while those range from 1103 to $748^{\circ} \mathrm{C}$ as per the thermometer of Lindsley and Spencer (1982) (table 5). The overall CPX temperatures $\left(1110-1190^{\circ} \mathrm{C}\right)$ are almost similar to the equilibration temperatures of $\mathrm{Fe}-\mathrm{Ti}$ oxides $\left(1063-1103^{\circ} \mathrm{C}\right)$ of LBF. From this it can be inferred that the CPX and $\mathrm{Fe}-\mathrm{Ti}$ oxides are formed under similar conditions of differentiation and fractionation before extrusion. However, the CPX temperatures of $\mathrm{MBF}\left(900-1110^{\circ} \mathrm{C}\right)$ and $\mathrm{UBF}\left(1000-1140^{\circ} \mathrm{C}\right)$ are comparatively higher than equilibration temperatures of $\mathrm{Fe}-\mathrm{Ti}$ oxides of $\mathrm{MBF}$ $\left(750-906^{\circ} \mathrm{C}\right)$ and $\mathrm{UBF}\left(748-899^{\circ} \mathrm{C}\right)$. This means that the CPX crystallization is earlier than $\mathrm{Fe}-\mathrm{Ti}$ oxide minerals re-equilibration, which indicates that the CPX temperatures represent the approximate eruption temperature of Pangdi basalt flows. The eruption temperatures deduced for Pangidi basalts are sufficiently in good agreement with eruption temperatures reported for the tholeiitic basalts $\left(1050-1150^{\circ} \mathrm{C}\right)$ of Mahabaleswar lavas of DVP (Sen 1986). The geochemical and isotopic data provide the evidence that the Ambaneli and Mahabaleswar lavas of SE DVP are established as genetically and topographically end points exposed as LBF and UBF at Pangidi area of eastern

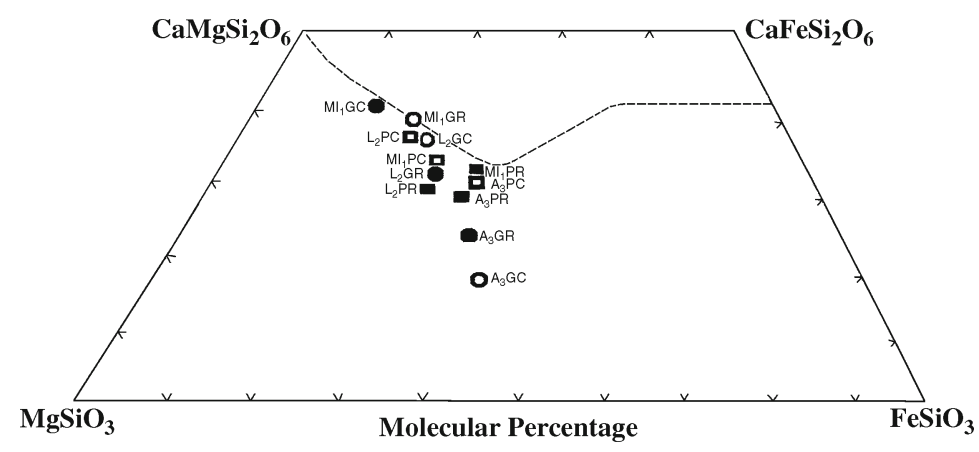

Figure 10. Classification diagram of Di-Hd-En-Fs for pyroxenes. $\mathrm{A}_{3}, \mathrm{MI}_{1}$ and $\mathrm{L}_{2}$ denote samples; PC, PR, GC and GR denote phenocryst core, phenocryst rim, groundmass core and groundmass rim. 


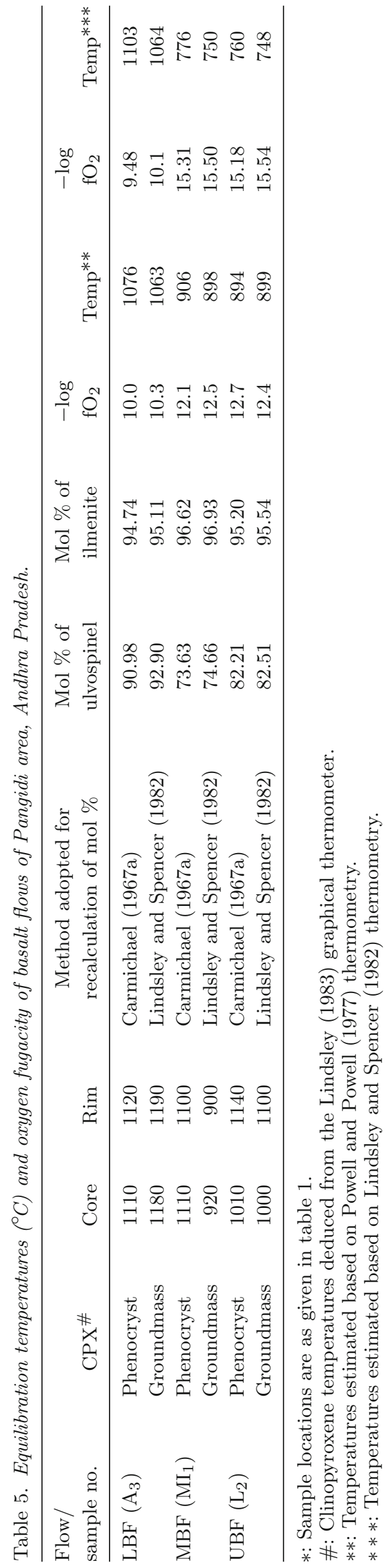

India (Baksi 2001; Knight et al 2003; Anne and Widdowson 2008).

High temperatures and $-\log \mathrm{fO}_{2}$ in LBF (1063$1103^{\circ} \mathrm{C} ; 9.48-10.3$ ) and medium to low temperatures and $-\log \mathrm{fO}_{2}$ in $\mathrm{MBF}\left(750-906^{\circ} \mathrm{C} ; 12.1-\right.$ $15.51)$ and $\mathrm{UBF}\left(748-899^{\circ} \mathrm{C} ; 12.4-15.54\right)$ are recorded in the Pangidi basalt samples. The values of $-\log \mathrm{fO}_{2}$ and equilibration temperatures of $\mathrm{Fe}-\mathrm{Ti}$ oxides of the present study are plotted in figure 12. The data fall in between QFM and NNO curves in general, but majority is close to the QFM curve (after Eugster and Wones 1962). It is suggested that during crystallization of the Pangidi basalt flows, prevailing $-\log \mathrm{fO}_{2}$ followed the values of a fayalite-magnetite-quartz buffer curve, indicating the tholeiitic composition of varied nature. This suggests that parent magma suffered limited fractionation in LBF at higher temperatures under increasing $-\log \mathrm{fO}_{2}$ whereas more fractionation at medium to lower temperatures under decreasing $-\log \mathrm{fO}_{2}$ conditions in $\mathrm{MBF}$ and UBF during the cooling. Mahabaleswar basalt samples that lie parallel to the QFM curve (figure 3b; Ahmad and Shrivastava 2004), indicate that more evolved tholeiitic basalts have witnessed high temperature and $-\log \mathrm{fO}_{2}$. The difference in $-\log \mathrm{fO}_{2}$ of Pangidi basalts suggests the oxidizing conditions of LBF and extremely reducing conditions of MBF and UBF prevailed at the time of cooling, as the eruption of LBF took place in aqueous and MBF and UBF in humid to semi-arid environments, respectively (Lakshminarayana et al 2010).

Figure 13 shows the equilibration temperatures of $\mathrm{Fe}-\mathrm{Ti}$ oxides against the whole rock ratios $\left(\mathrm{FeO}+\mathrm{Fe}_{2} \mathrm{O}_{3}\right) /\left(\mathrm{FeO}+\mathrm{Fe}_{2} \mathrm{O}_{3}+\mathrm{MgO}\right)$ of the same basalt samples of Pangidi area. The liquidus data at 1 atmospheric pressure of the Hawaiian tholeiitic lavas is also shown (after Tilley et al 1963). The sample $\mathrm{A}_{3}$ of LBF data is clustered very closely to the Hawaiian tholeiite liquidus line at higher temperatures, while the $\mathrm{MI}_{1}$ of $\mathrm{MBF}$ and $\mathrm{L}_{2}$ of UBF fall below the liquidus line at medium to lower temperatures. It is suggested that the higher temperatures of $\mathrm{A}_{3}$ (LBF) is represented by the presence of more amounts of opaques and interstitial glass (table 1 ), whereas the medium to low temperatures of $\mathrm{MI}_{1}$ (MBF) and $\mathrm{L}_{2}$ (UBF) are due to vesicular nature which contains larger content of gases and humid and semi-arid atmospheric conditions during cooling, which corroborates the observations of Sethna et al (1987) and Ahmad and Shrivastava (2004). The temperature variations in the $\mathrm{LBF}, \mathrm{MBF}$ and $\mathrm{UBF}$ are expected due to the varied conditions of fractional crystallization of same parent tholeiitic magma at different times of intervals during differentiation process, thus erupted into three basalt flows in the Pangidi area of Andhra Pradesh. 


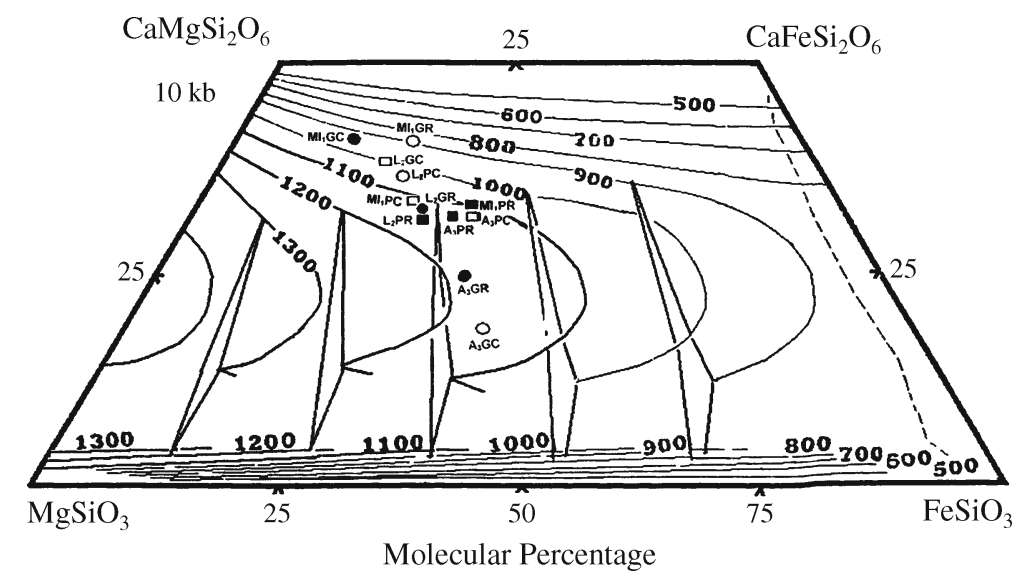

Figure 11. Graphical pyroxene thermometry (after Lindsley 1983). $\mathrm{A}_{3}, \mathrm{MI}_{1}$ and $\mathrm{L}_{2}$ denote samples; PC, PR, GC and GR denote phenocryst core, phenocryst rim, groundmass core and groundmass rim.

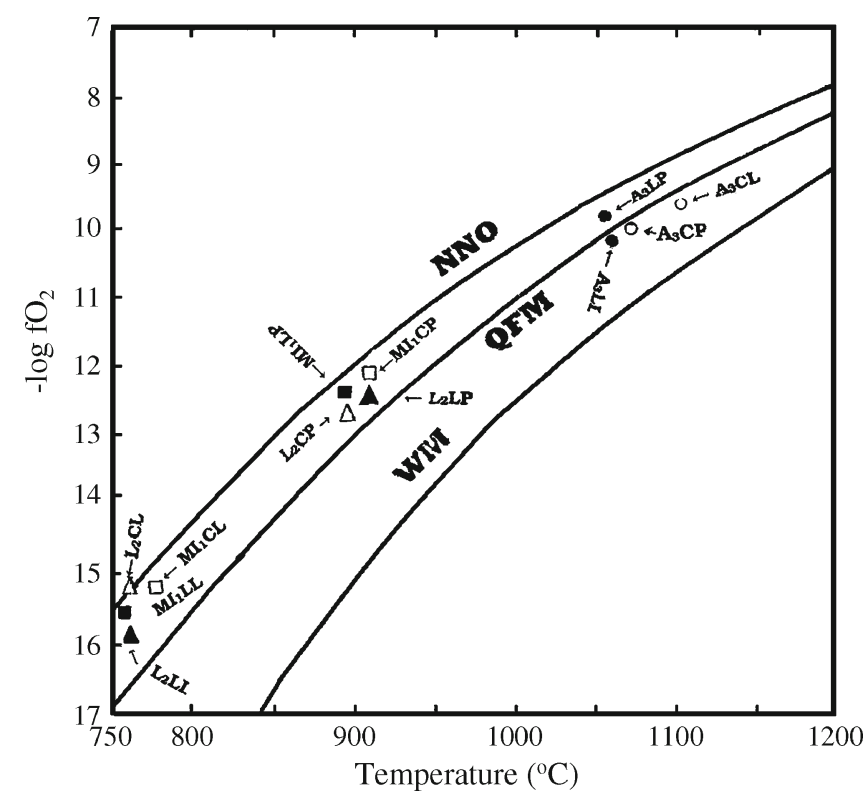

Figure 12. Temperature of equilibration vs. oxygen fugacity of Fe-Ti oxides. NNO, QFM and WM represent buffer curves for Nickel-Nickel, Quartz Fayalite Magnetite and Wutzite-Magnetite buffers respectively (after Eugster and Wones 1962). $\mathrm{A}_{3}, \mathrm{MI}_{1}$ and $\mathrm{L}_{2}$ denote samples; ' $\mathrm{C}$ ' denotes Carmichael (1967a) recalculation scheme; ' $L$ ' denotes Lindsley and Spencer (1981) scheme; ' $\mathrm{P}$ ' denotes Powell and Powell (1977) thermometer and 'L' denotes Lindsley and Spencer (1982) thermometer.

\section{Conclusions}

The higher An content of plagioclase and greater enrichment of iron in augite pyroxene indicate that the Pangidi basalts are derived from the parent tholeiitic magma. CPX temperatures represent the approximate eruption temperature of present lavas. $\mathrm{Fe}-\mathrm{Ti}$ oxides temperatures and $-\log \mathrm{fO}_{2}$ data follow the trend of QFM curve which infers that the

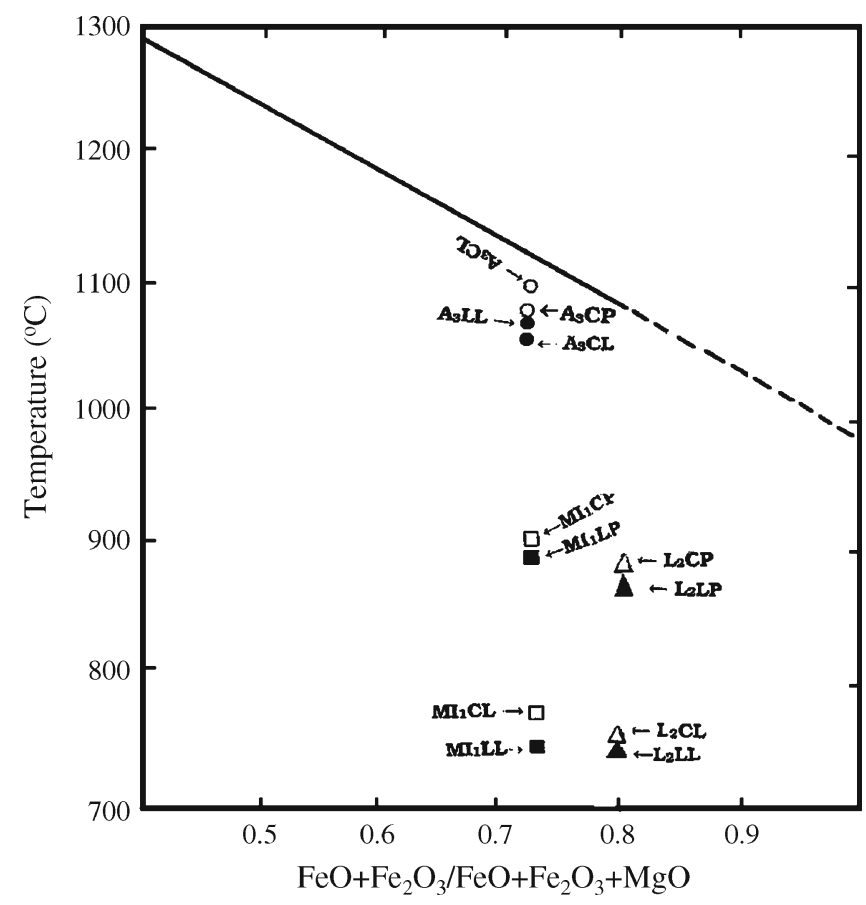

Figure 13. Iron-titanium oxides equilibration temperature plotted against the whole rock ratios: $\left(\mathrm{FeO}+\mathrm{Fe}_{2} \mathrm{O}_{3}\right) /$ $\left(\mathrm{FeO}+\mathrm{Fe}_{2} \mathrm{O}_{3}+\mathrm{MgO}\right)$ of host rock. The line represents the liquidus data at 1 atmosphere for Hawaiian tholeiitic lava (after Tilley et al 1963). $\mathrm{A}_{3}, \mathrm{MI}_{1}$ and $\mathrm{L}_{2}$ denote samples; 'C' denotes Carmichael (1967b) recalculation scheme; ' $\mathrm{L}$ ' denotes Lindsley and Spencer (1981) scheme; ' $\mathrm{P}$ ' denotes Powell and Powell (1977) thermometer and ' $L$ ' denotes Lindsley and Spencer (1982) thermometer. The above used whole rock data of $\mathrm{FeO}, \mathrm{Fe}_{2} \mathrm{O}_{3}$ and $\mathrm{MgO}$ of the $\mathrm{A}_{3}, \mathrm{MI}_{1}$ and $\mathrm{L}_{2}$ samples are adopted from Nageswara Rao et al (2008).

LBF suffered a limited fractionation at higher temperatures under increasing $-\log \mathrm{fO}_{2}$ whereas the $\mathrm{MBF}$ and $\mathrm{UBF}$ are more involved in fractionation under decreasing $-\log \mathrm{fO}_{2}$ conditions. The high $\mathrm{Fe}-\mathrm{Ti}$ oxides equilibration and $-\log \mathrm{fO}_{2}$ of $\mathrm{LBF}$ 
and medium to lower temperatures and $-\log \mathrm{fO}_{2}$ of $\mathrm{MBF}$ and UBF represent the oxidation conditions in $\mathrm{LBF}$ and extreme reducing conditions in $\mathrm{MBF}$ and UBF at the time of eruption and cooling.

\section{Acknowledgements}

The authors gratefully acknowledge the Director, National Geophysical Research Institute, Hyderabad for his generous help to carry out the EPMA analysis. Thanks are due to Dr K Rameshwara Rao, Scientist, Wadia Institute of Himalayan Geology, Dehradun for his help to run the ITHERM program. The authors are also thankful to Prof N Subba Rao, Department of Geology, Andhra University for the critical reading to improve the paper.

\section{References}

Ahmad M and Shrivastava J P 2004 Iron-titanium oxide geothermometry and petrogenesis of lava flows and dykes from Mandla lobe of the eastern Deccan Volcanic Province, India; Gondwana Res. 7(2) 567-577.

Anne E J and Widdowson M 2008 Stratigraphy, structure and volcanology of southeast Deccan continental flood basalt province: Implications for eruptive extent and volumes; J. Geol. Soc. London 165 177-188.

Baksi A K, Byerly G R, Chan L H and Farrar E 1994 Intracanyon flows in the Deccan Province, India? Case history of the Rajahmundry traps; Geol. 22 605-608.

Baksi A 2001 The Rajahmundry Traps, Andhra Pradesh: Evaluation of their petrogenesis relative to the Deccan traps; Proc. Indian Acad. Sci. 110 397-407.

Brown G M and Vincent E A 1963 Pyroxenes from the early and middle staes of fractionation of the Skaergaard intrusion, East Greenland; J. Petrol. 4 175-197.

Brown G M 1967 Mineralogy of basaltic rocks; In: The Poldervaart treatise on rocks of basaltic composition, Interscience Publishers 1 103-167.

Carmichael I E S 1967a The Iron-titanium oxides of salic volcanic rocks and their associated ferromagnesian silicates; Contrib. Mineral. Petrol. 14 36-64.

Carmichael I E S 1967b The mineralogy of Thingmuli, a tertiary volcano in eastern Iceland; Am. Mineral. 52 1815-1841.

Eugster H P and Wones D R 1962 Stability relations of the ferruginous biotite, annite; J. Petrol. 3 82-125.

Hennoc J and Maurice F C 1978 Microanalyses and scanning electron microscopy; In: Las Editors de Physique (eds) Maurice F, Mony L and Tixer R, Oragy, pp. 281-307.

Knight K B, Renne P R, Halkett A and White N 2003 ${ }^{40} \mathrm{Ar} /{ }^{39} \mathrm{Ar}$ dating of the Rajahmundry Traps, eastern India and their relationship to the Deccan Traps; Earth Planet. Sci. Lett. 208 85-99.
Lakshminarayana G, Manikyamba C, Tarun C, Khanna P, Kanakadande P and Raju K 2010 New observations on Rajahmundry Traps of the Krishna-Godavari Basin; J. Geol. Soc. India 75 807-819.

Lindsley D H and Spencer K J 1982 Fe-Ti oxide geothermometry: Reducing analyses of coexisting Ti-magnetite (Mt) and ilmenite (Ill); Trans. Am. Geophys. Union 6347.

Lindsley D H 1983 Pyroxene thermometry; Am. Mineral. 68 477-493.

Mahoney J J, Macdougal J D, Lugmuir G W, Murali A V, Sankar Das M and Gopalan K 1982 Origin of the Deccan Trap flows at Mahabaleswar inferred from Nd and Sr isotopic and chemical evidence; Earth Planet. Sci. Lett. 60 47-60.

Nageswara Rao P V, Swaroop P C and Ranga Rao V 2008 Geochemistry and origin of basalt flows of Rajahmundry area, Andhra Pradesh, southeast India; Gond. Geol. Mag. 23(2) 91-102.

Najafi S J, Cox K G and Sukeshwala R N 1981 Geology and geochemistry of the basalt flows (Deccan Traps) of the Mahad-Mahabaleswar section, India; In: Deccan Volcanism (eds) Subba Rao K V and Sukeshwala R N, Geol. Soc. India Memoir 3 300-315.

Powell M and Powell R 1977 Geothermometry and oxybarometry using coexisting iron-titanium oxides: A reappraisal; Mineral. Mag. 41 257-263.

Rameshwara Rao D, Choubey Vinay M and Subba Rao T V 1991 ITHERM: A basic program for magnetite and ilmenite thermometry; Comp. Geosci. 17 307-314.

Raju D S N, Rao C N and Sengupta B K 1965 Paleocurrents in Miocene Rajahmundry formation, Andhra Pradesh, India; J. Sedim. Petrol. 35 758-762.

Rao A T, Srinivasa Rao K and Vijaya Kumar V 2002 Basic volcanism along K-boundary from Rajahmundry, east coast of India; J. Geol. Soc. India 60 583-586.

Self S, Jay A E, Widdowson M and Kaszthelyi L P 2008 Corelation of the Deccan and Rajahmundry trap lavas: Are these the longest and largest lava flows on Earth?; J. Vol. Res. 172 3-19.

Sen G 1986 Mineralogy and petrogenesis of the Deccan Trap flows around Mahabaleswar; J. Petrol. 27 627-663.

Sethna S F, Czygan W and Sethna B S 1987 Iron-titanium oxide geothermometry for some Deccan Trap tholeiitic basalts, India; J. Geol. Soc. India 29 483-488.

Sethna S F and Sethna B S 1988 Mineralogy and petrogenesis of Deccan Trap basalts from Mahabaleswar, Igatpuri, Sagar-Nagpur areas, India; In: Deccan Flood Basalts (ed.) Subba Rao K V, J. Geol. Soc. India Spec. Publ. 10 69-90.

Spencer K J and Lindsley D H 1981 A solution model for coexisting iron-titanium oxides; Am. Mineral. 66 1189-1201.

Subba Rao K V, Bodas M S, Hooper P R and Walsh J N 1988 Petrogenesis of Jawhar and Igatpuri formations western Deccan Basalt Province; In: Deccan Flood Basalts (ed.) Subba Rao K V, J. Geol. Soc. India Spec. Publ. 10 253-280.

Tilley C S, Yoder H S and Schairer J F 1963 Melting relations of basalts; Carnegie Inst., Washington Year Book $6277-84$. 